Article

\title{
Effect of Manganese Chloride and of Cotreatment with Cadmium Chloride on the In Vitro Proliferative, Motile, and Invasive Behavior of MDA-MB231 Breast Cancer Cells
}

\author{
Claudio Luparello $\mathbb{D}$ \\ Dipartimento di Scienze e Tecnologie Biologiche, Chimiche e Farmaceutiche (STEBICEF), Università di Palermo, \\ 90128 Palermo, Italy; claudio.luparello@unipa.it; Tel.: +39-091-2389-7405
}

Academic Editors: Carlo Santini and Maura Pellei

check for

Received: 7 March 2019; Accepted: 25 March 2019; Published: 27 March 2019

updates

\begin{abstract}
We examined the dose-response effect of $\mathrm{MnCl}_{2}$ on the proliferative behavior of triple-negative breast cancer MDA-M231 cells vs. immortalized HB2 cells from breast epithelium taken as nontumoral counterparts. We also tested the effect of $\mathrm{MnCl}_{2}$ on tumor cell invasiveness in vitro by evaluating the relative invasion indexes through Boyden chamber assays. Moreover, we checked whether cotreatment with both $\mathrm{MnCl}_{2}$ and $\mathrm{CdCl}_{2}$ could modify the observed biological response by MDA-MB231 cells. Our results show a promotional impact of $\mathrm{MnCl}_{2}$ on cell proliferation, with $5 \mu \mathrm{M}$ concentration inducing the more pronounced increase after 96-h exposure, which is not shared by $\mathrm{HB} 2$ cells. Exposure to $5 \mu \mathrm{M} \mathrm{MnCl}_{2}$ induced also an elevation of the relative invasion index of cancer cells. The Mn-mediated stimulatory effects were counteracted by cotreatment with $\mathrm{CdCl}_{2}$. These data support the concept that human exposure to high environmental concentrations of $\mathrm{Mn}$ may increase the risk of carcinogenesis and metastasis by prompting the expansion and dissemination of triple-negative breast cancer cells. On the other hand, the Mn-counteracting anticancer property of $\mathrm{Cd}$ looks promising and deserves a more detailed characterization of the involved intracellular targets aimed to the molecular modeling of specific antineoplastic agents against malignant breast cancer spreading.
\end{abstract}

Keywords: breast cancer cells; manganese; cadmium; proliferation; chemotaxis; chemoinvasion

\section{Introduction}

Manganese (Mn) is a natural occurring element in the earth's crust where it represents the twelfth most abundant one. It is not found in nature as a pure metal but as a component of several inorganic and organic compounds. In industry, the major implementations of Mn include steel production and the alloying of aluminum. The major dietary source of Mn for humans is vegetables, e.g., cereals, whole grain, and nuts, and usually $\mathrm{Mn}$ intake from food is higher than that from water. However, since the environmental concentration of the metal may be elevated by anthropogenic activities such as industrial emissions, fossil fuel combustion, and use of pesticides, this can result in its release into and contamination of drinking water with consequent increase of human exposure. At cellular level, $\mathrm{Mn}$ is an essential micronutrient which can be found as a component of a broad variety of metalloenzymes involved in processes related to energy production, general metabolism, bone and connective tissue formation, and blood clotting [1,2]. Mn uptake by mammalian cells is mediated by different transporters, such as the divalent metal transporter -1 (DMT-1) and Zrt- and Irt-like proteins (ZIP) 8 and $14[3,4]$, which show affinity also for other divalent metals, i.e., cadmium (Cd) and zinc $(\mathrm{Zn})$. 
Triple-negative breast cancers (TNBC) are characterized by a highly "aggressive" malignant potential thereby being usually associated with worse prognosis than other breast tumor types, due to the lack of expression of estrogen and progesterone receptors and HER2/neu, which renders these neoplastic cells poorly responsive to hormonal therapies and to HER2-targeting drugs [5]. A number of case-control studies have found a significant association between serum Mn levels and the development of malignant breast cancer in humans [6,7] and rodents [8], thus prompting a more detailed biological investigation of the cellular and molecular implications of breast cell exposure to $\mathrm{Mn}$. To this purpose, the MDA-MB231 cell line represents a suitable model system in vitro, being derived from a pleural effusion of a TNBC of basal subtype and displaying several aspects of a highly malignant phenotype, e.g., the inactivation of p53 dependent upon a mutation in codon 280 and the ability to metastasize in vivo [9-11]. The number of studies concerning the effect of Mn on MDA-MB231 cells that can be found in the literature is limited. In particular, Lymburner et al. [12] demonstrated that, among other divalent cations, Mn acts as the strongest promoter of integrin-mediated adhesion of MDA-MB231 cells to fibronectin, whereas Ju et al. [13] reported a downregulation of MDA-MB231 cell growth and motility in the presence of Mn-12 acetate.

In the present study we have investigated the dose-response effect of different concentrations of $\mathrm{MnCl}_{2}$ on MDA-M231 cell viability/growth comparing cell behavior with that of immortalized HB2 cells from breast epithelium taken as a nontumoral counterpart. We have further examined the effect of $\mathrm{MnCl}_{2}$ on TNBC cells with respect to invasiveness in vitro by evaluating specific parameters such as invasion index (I.I.) and relative invasion index (R.I.I.). Moreover, taking into consideration that $\mathrm{Mn}$ and $\mathrm{Cd}$ share and compete for the same membrane transporters [14-16] and that we [17-19] previously demonstrated and characterized the cytotoxic effect exerted by exposure of MDA-MB231 cells to $\mathrm{CdCl}_{2}$, we checked whether coexposure of MDA-MB231 cells to both $\mathrm{MnCl}_{2}$ and $\mathrm{CdCl}_{2}$ could somehow modify the biological response of TNBC cells with respect to the treatment with the sole $\mathrm{MnCl}_{2}$.

\section{Results}

\subsection{Influence of $\mathrm{MnCl}_{2}$ on Cell Proliferative and Invasive Behavior In Vitro}

In the first set of assays we checked the effect of exposure to increasing concentrations of $\mathrm{MnCl}_{2}$ for various time lapses on the proliferative behavior of MDA-MB231 TNBC cells via crystal violet assay. In addition, parallel experiments were performed on HB2, an immortalized cell line obtained from breast epithelium, taken as a non-neoplastic counterpart. Figure 1A shows the dose- and time-response histograms of viability/growth of MDA-MB231 cells as the percentage of dye absorbance in wells with respect to controls. The data obtained indicate that 96-h treatments with 1, 5, 10, and $50 \mu \mathrm{M}$ $\mathrm{MnCl}_{2}$ determined an approximate $32,52,47$, and $32 \%$ increase of cell population, respectively, although an initial decrease of cell number could be observed in the presence of 10 and $50 \mu \mathrm{M}$ concentrations of the molecule. The dose-time response pattern after exposure to $100 \mu \mathrm{M} \mathrm{MnCl}{ }_{2}$ was symptomatic of a viability- and growth-restraining activity exerted by the molecule at this high concentration on the breast cancer cell line. On the other hand, as shown in Figure 2B, when HB2 cells were submitted to the same analysis for comparison, their proliferative behavior was not remarkably modified by the presence of $\mathrm{MnCl}_{2}$, and, also in this case, at the higher concentrations tested, i.e., 50 and $100 \mu \mathrm{M}$, the number of attached cells was found to diminish over time. 


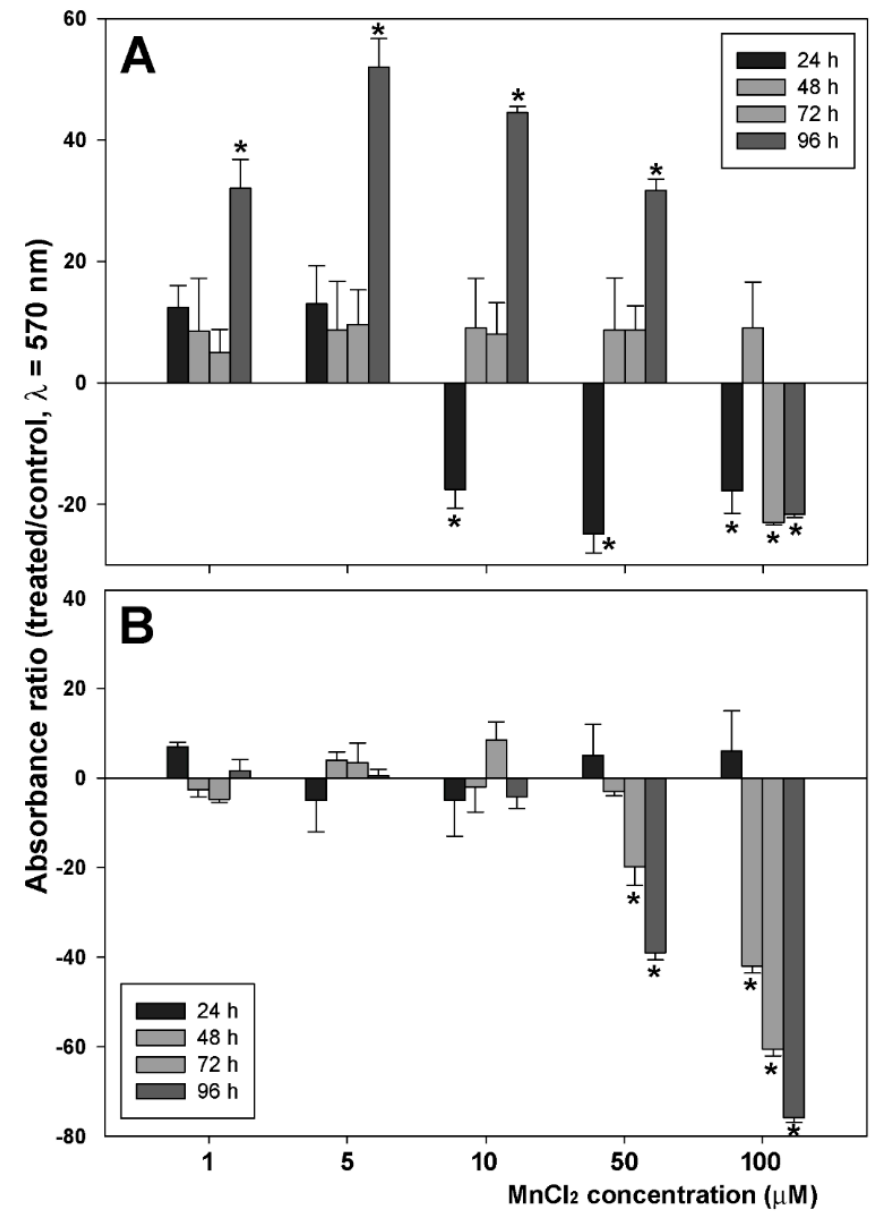

Figure 1. Effect of exposure of MDA-MB231 (A) and HB2 (B) cells to different concentrations of $\mathrm{MnCl}_{2}$ for $24,48,72$, and $96 \mathrm{~h}$. The histogram shows the percent ratio between the crystal violet absorbance of exposed cells and that of untreated controls. Four replicates were run for each assay. The results are expressed as the mean \pm standard error of the mean (SEM) from quadruplicate assays. Four replicates were run for each assay. ${ }^{*} p<0.05$.
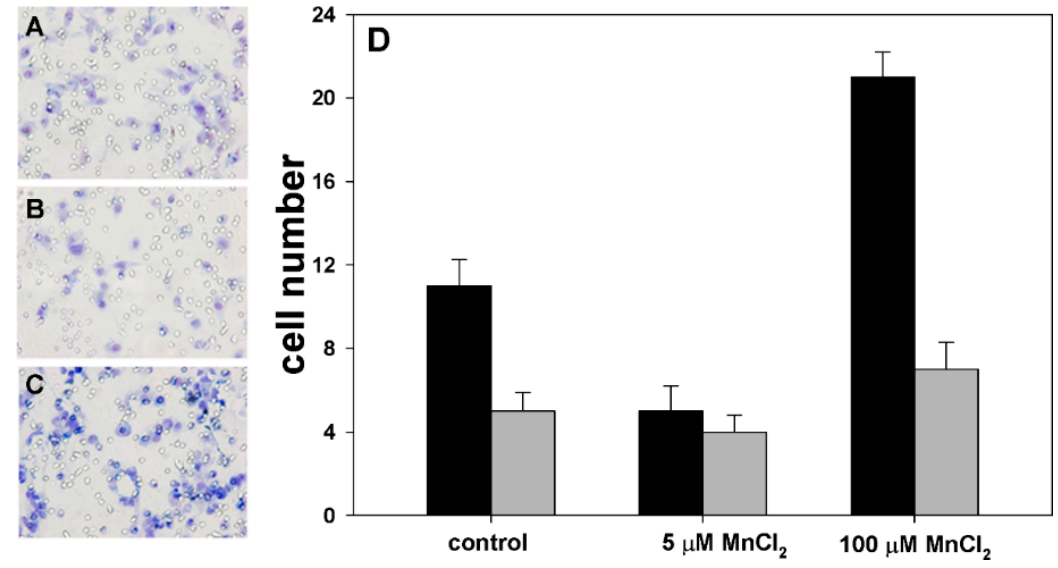

Figure 2. Representative low-magnification images captured at 6-h showing that control, (A) $5 \mu \mathrm{M}$ $\mathrm{MnCl}_{2}$-treated (B), and $100 \mu \mathrm{M} \mathrm{MnCl}$-treated cells (C) migrated through the filter pores in the chemotaxis assays. Microscopic magnification $=40 \times$. (D) Histogram showing the number of migrated cells in chemotaxis (black bars) and chemoinvasion assays (gray bars) in the two experimental conditions. The results are expressed as the mean \pm standard error of the mean (SEM) of six different experiments. 
We then extended our study of $\mathrm{MnCl}_{2}$ effects on MDA-MB231 cancer cells by examining their locomotory and invasive behavior in vitro after exposure for $96 \mathrm{~h}$ to either 5 or $100 \mu \mathrm{M}$ concentrations of the molecule, which in the proliferation assays induced higher increase and decrease of the cell population, respectively. When cells were cultured in these two experimental conditions, as shown in Figure 2, an opposite modulation of cell motility in Boyden chamber assays was observed.

In fact, the average migration ratio between either 5- or $100 \mu \mathrm{M} \mathrm{MnCl}_{2}$-exposed cells and controls was 0.45 and 1.9, respectively, in the chemotaxis assays, and 0.8 and 1.4 in the chemoinvasion assays.

In light of the data obtained, we calculated the I.I.s and the R.I.I., a parameter which, taking both cell chemotactic and chemoinvasive behaviors into consideration, is useful to extrapolate the actual modulation of in vitro invasiveness within the general phenomenon of cell mobilization (see e.g., Luparello, C.; et al. [9]). Although the general motile attitude appeared to increase in cells treated with $100 \mu \mathrm{M} \mathrm{MnCl}_{2}$, when I.I.s and R.I.I.s were evaluated, exposure to $5 \mu \mathrm{M} \mathrm{MnCl}_{2}$ appeared to upregulate drastically the ability of the subpopulation of locomotion-triggered cells to penetrate the three-dimensional matrix (control cells' I.I. = 0.36; treated cells' I.I. = 1; R.I.I. = 2.78), whereas exposure to $100 \mu \mathrm{M}$ concentration of the molecule, which promoted the motility of a larger cell population, resulted in a slight downregulation of cell invasive potential (control cells' I.I. $=0.36$; treated cells' I.I. = 0.33; R.I.I. = 0.92).

\subsection{Effect of Coexposure to $\mathrm{MnCl}_{2}$ and $\mathrm{CdCl}_{2}$ on Cell Proliferative and Invasive Behavior In Vitro}

We have previously reported that $\mathrm{CdCl}_{2}$ is able to restrain MDA-MB231 cell viability and growth with an $\mathrm{IC}_{50}$ of $5 \mu \mathrm{M}$ at 96-h [17]. Therefore, in a second set of experiments we examined the effect of addition of $5 \mu \mathrm{M} \mathrm{CdCl}_{2}$ in the experimental conditions previously tested on MDA-MB231 cell proliferative behavior after 96-h exposure. Figure 3 shows the dose-response histogram as the percentage of dye absorbance in wells with respect to controls, i.e., cells treated with $\mathrm{MnCl}_{2}$ only. The data obtained indicate that $\mathrm{CdCl}_{2}$ was able to decrease cell growth down to $\sim 22-27 \%$ of controls in all the experimental conditions tested, including treatment with $100 \mu \mathrm{M} \mathrm{MnCl}_{2}$ that was the sole condition where no upregulation of cell number was found. Therefore, this result gives evidence that coexposure to $\mathrm{CdCl}_{2}$ determines a generalized reversion of $\mathrm{MnCl}_{2}$-induced promotion of MDA-MB231 cell proliferative behavior.

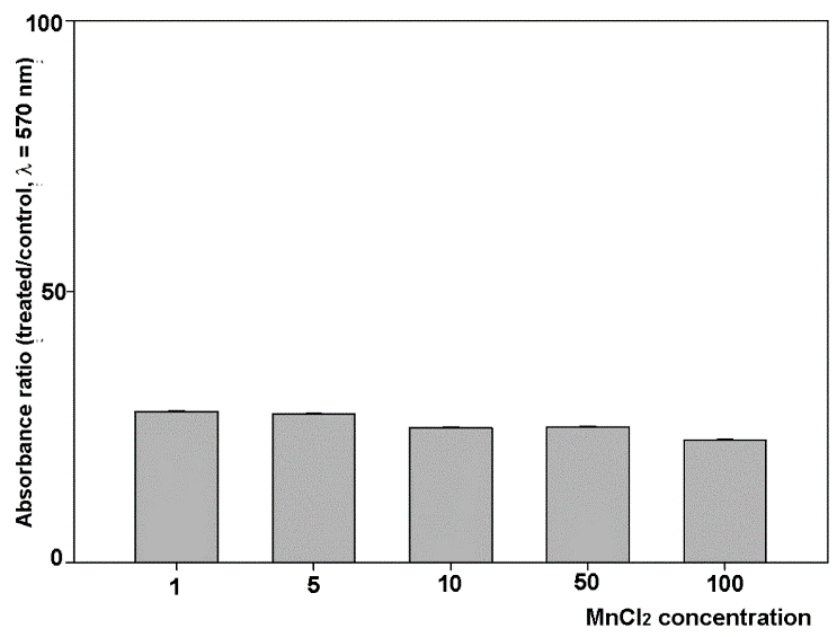

Figure 3. Effect of coexposure of MDA-MB231 cells to both $5 \mu \mathrm{M} \mathrm{CdCl}_{2}$ and different concentrations of $\mathrm{MnCl}_{2}$ for $96 \mathrm{~h}$. The histogram shows the percent ratio between the crystal violet absorbance of coexposed cells and that of controls, i.e., cells treated with the sole $\mathrm{MnCl}_{2}$ at the indicated concentrations. Results are from quadruplicate crystal violet assays. Four replicates were run for each assay. The results are expressed as the mean \pm standard error of the mean (SEM). 
The effect of coexposure of $\mathrm{MnCl}_{2}$ with $5 \mu \mathrm{M} \mathrm{CdCl} 2$ on cell invasive behavior was also checked. Therefore, in preliminary assays we evaluated MDA-MB231 cell behavior in chemotaxis and chemoinvasion assays after exposure for $96 \mathrm{~h}$ to $5 \mu \mathrm{M} \mathrm{CdCl}_{2}$. Figure 4 shows that, in line with the previously observed inhibitory effect on cell viability and growth [17], $\mathrm{CdCl}_{2}$ treatment determined a decrease of cell chemotactic ability with an average migration ratio between exposed and control cells of 0.66 . Analogously, we found a decrease also in cell chemoinvasive ability through three-dimensional reconstituted basement membrane, the average migration ratio accounting for 0.57. The average I.I.s of control and treated cells were found to account for 77 and 67, respectively, and consequently the average R.I.I. of treated cells was 0.87 thus confirming the invasion-restraining effect of cell exposure to $\mathrm{CdCl}_{2}$.
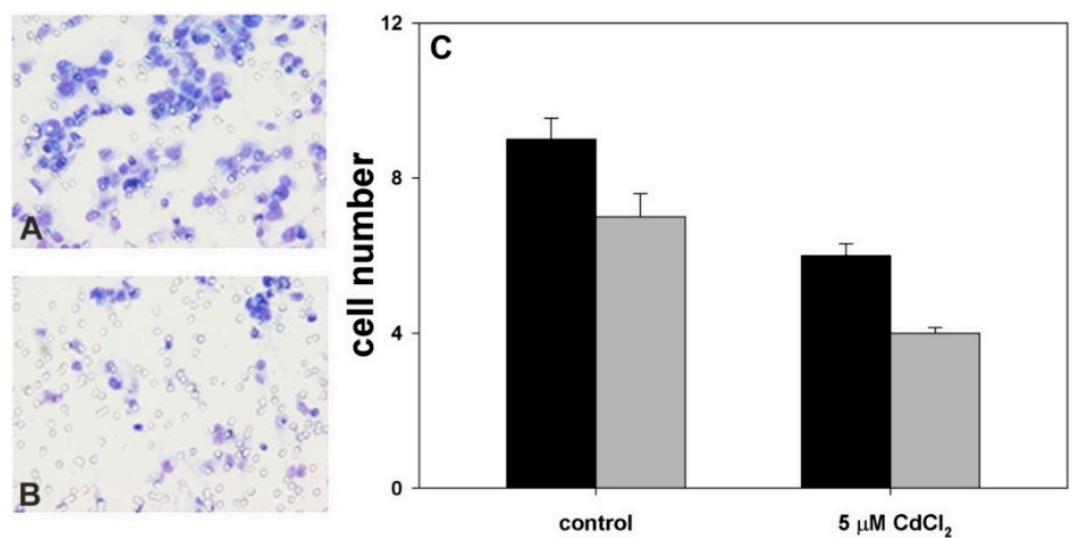

Figure 4. Representative low-magnification images captured at $6 \mathrm{~h}$ showing control (A) and $5 \mu \mathrm{M} \mathrm{CdCl}_{2}$-treated MDA-MB231 cells (B) migrated through the filter pores in chemotaxis assays. Microscopic magnification $=40 \times$. (C) Histogram showing the number of migrated cells in chemotaxis (black bars) and chemoinvasion assays (gray bars) in the two experimental conditions. The results are expressed as the mean \pm standard error of the mean (SEM) of six different experiments.

In light of the observed stimulatory role played by $\mathrm{MnCl}_{2}$ on cell motility or invasiveness in Boyden chamber tests, we examined whether the addition of $5 \mu \mathrm{M} \mathrm{CdCl}_{2}$ in $\mathrm{MnCl}_{2}$-containing media could induce any change in the locomotory or invasive attitude of breast cancer cells. Figure 5 shows that $\mathrm{CdCl}_{2}$ was able to downregulate the effect of $\mathrm{MnCl}_{2}$ on cell invasive potential shown in Figure 2. In particular, the coexposure to $5 \mu \mathrm{M} \mathrm{MnCl}_{2}$ appeared to determine an average migration ratio vs. controls (i.e., cell exposed to $5 \mu \mathrm{M} \mathrm{MnCl}_{2}$ only) of 0.5 in both chemotaxis and chemoinvasion tests, respectively, whereas in the case of cotreatment with $100 \mu \mathrm{M} \mathrm{MnCl}_{2}$, the average migration ratio vs. controls (i.e., cell exposed to $100 \mu \mathrm{M} \mathrm{MnCl}_{2}$ only) decreased down to 0.19 and 0.14 in chemotaxis and chemoinvasion tests, respectively. On the other hand, when the R.I.I.s were quantitated their values appeared to diminish in both experimental conditions of coexposure, being 1 in the presence of $5 \mu \mathrm{M} \mathrm{MnCl}_{2}$ (control cells' I.I. $=1$, co-treated cells' I.I. $=1$ ) and 0.75 in the presence of $100 \mu \mathrm{M} \mathrm{MnCl}_{2}$ (control cells' I.I. $=0.33$, cotreated cells' I.I. $=0.25$ ). 

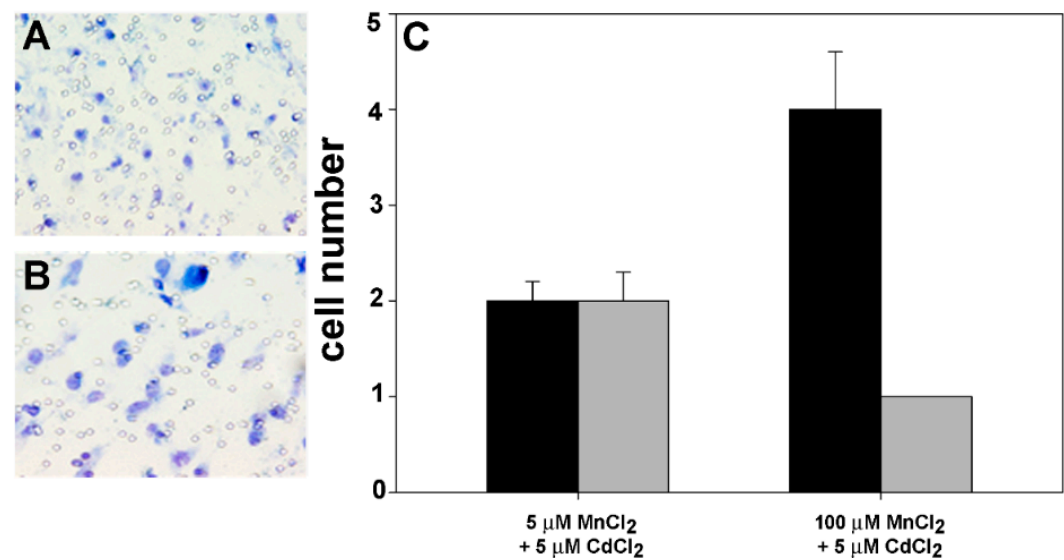

Figure 5. Representative low-magnification images captured at $6 \mathrm{~h}$ showing $5 \mu \mathrm{M} \mathrm{MnCl}_{2} / 5 \mu \mathrm{M} \mathrm{CdCl}_{2}$ cotreated (A) and $100 \mu \mathrm{M} \mathrm{MnCl}_{2} / 5 \mu \mathrm{M} \mathrm{CdCl}_{2}$ cotreated MDA-MB231 cells (B) migrated through the filter pores in chemotaxis assays. Microscopic magnification $=40 \times$. (C) Histogram showing the number of migrated cells in chemotaxis (black bars) and chemoinvasion assays (gray bars) in the different experimental conditions. The results are expressed as the mean \pm standard error of the mean (SEM) of six different experiments.

\section{Discussion}

In the present paper, we have tested the effect of increasing concentrations of $\mathrm{MnCl}_{2}$ on the proliferative, locomotory, and invasive behavior of TNBC MDA-MB231 cells. All the concentrations chosen, including the lowest one, i.e., $1 \mu \mathrm{M}$, are higher than those estimated in healthy adults' physiological fluids such as blood and milk [20,21], and therefore the experimental conditions are representative of states of moderate to intense environmental contamination. Noteworthy, in their early case-control study Mulay et al. [22] demonstrated the increase of Mn concentration in malignant human breast tissues with respect to their normal counterparts, whereas Dearth et al. [8] reported that exposure of prepubertal rats to environmentally relevant high Mn concentrations increases their susceptibility to breast cancer risk via upregulation of $\mathrm{ER} \alpha$ and associated proteins. In line with these observations, our first set of data on cell proliferative behavior show a promotional impact of $\mathrm{MnCl}_{2}$, except for the highest concentration tested of $100 \mu \mathrm{M}$, which is not shared by non-neoplastic HB2 breast cells. Interestingly, in previous experiments $\mathrm{HB} 2$ cells resulted insensitive also to the cytotoxic effect of $\mathrm{CdCl}_{2}$ when administered at a concentration equivalent to the $\mathrm{IC}_{50}$ at $96 \mathrm{~h}$ for MDA-MB231 cells [17]. When breast cancer cells were assayed for their motility and invasiveness through matrigel after exposure to the two $\mathrm{MnCl}_{2}$ concentrations exerting opposite growth effects after $96 \mathrm{~h}$ of incubation, i.e., 5 and $100 \mu \mathrm{M}$, they exhibited a stimulation of their motile, but not invasive, attitude in the presence of the higher concentration, whereas those cultured in $5 \mu \mathrm{M} \mathrm{MnCl}{ }_{2}$-containing medium appeared endowed also with a marked upregulation of their invasive, other than proliferative, phenotype. It is known that, in addition to the activation of the locomotory ability, highly invasive MDA-MB231 subpopulations selected using Boyden chambers display (i) the upregulation of urokinase-plasminogen activator $(\mathrm{uPa}) / \mathrm{uPa}$ receptor expression and of metalloproteinase (MMP) activity, and (ii) an epithelial-mesenchymal transition leading to a weaker attachment to extracellular matrix (ECM) molecules (such as matrigel components) due to the downregulation of genes involved in cell-ECM adhesion and cell-cell junctions [23]. Both aspects support cell infiltration and crossing through the three-dimensional matrigel layer.

Among the enzymes that use $\mathrm{Mn}$ as a cofactor, manganese superoxide dismutase (MnSOD) is a likely candidate as responsible of the observed effect. MnSOD is a mitochondrial tetrameric protein contributing to the maintenance of redox balance and intact respiratory function via the dismutation of the superoxide radical to oxygen and hydrogen peroxide, the latter being subsequently metabolized by hydrogen peroxide-detoxifying enzymes [24]. High levels of MnSOD gene (i.e., SOD2) 
expression have been found in different cancers and correlated to poor prognosis, low relapse-free survival and overall survival rate. Concerning breast cancer, SOD2 expression levels are different in the various histotypes, being upregulated in both tissue specimens and cell lines derived from the more "aggressive" basal-like, claudin low-, and estrogen receptor-negative subtype, including MDA-MB231 [25]. Kattan et al. [26] reported that the elevated expression level of SOD2 in MDA-MB231 cells is coupled to a downregulation of the detoxifying enzymes, thereby resulting in an accumulation of hydrogen peroxide, which, in turn, stimulates cell growth via activation of the MAPK-dependent signalization and transcription factors such as NF- $\mathrm{B}$ and AP-1. Conversely, low levels of MnSOD protein were found in nontumoral breast epithelial cell lines, such as MCF-10A [27]. A number of experimental evidence has demonstrated that, apart from upregulating MnSOD activity, Mn promotes SOD2 expression in different biological systems [28,29], including Hs578T TNBC cells [30]. Therefore, it is conceivable that exposure of $\mathrm{MDA}-\mathrm{MB} 231$ cells to $\mathrm{MnCl}_{2}$ may determine an additional dose- and time-dependent upregulation of MnSOD with consequent increase of cell number. Moreover, by analogy with Hs578T line which was induced to death by $\mathrm{MnCl}_{2}$ above $100 \mu \mathrm{M}$, such concentration impaired also MDA-MB231 cell viability and proliferation. As hypothesized by Thongphasuk et al. [30], such an effect could be due to excess of free radicals and/or high glucose consumption during the redox cycle to supply reducing equivalents. On the other hand, similarly to what was found for the syngeneic Hs578Bst cell line derived from adjacent normal tissue, no effect was exerted by $\mathrm{MnCl}_{2}$ treatment on nontumoral $\mathrm{HB} 2$ cells, apart from the intoxication at high concentration of the compound as for tumor cells. Such insensitivity might be explained in light of (i) the demonstrated heterogeneity of cell-specific SOD2 stimulants resulting in the inability of Mn to upregulate the enzymatic activity in certain cytotypes, (ii) the low levels of MnSOD enzyme which may be saturated at nanomolar concentrations of Mn without further dose-dependent stimulation of enzyme function, as reported by [28], and/or (iii) the presence of a more efficient hydrogen peroxide-detoxifying apparatus [30].

The involvement of MnSOD in cell invasive activity is also widely recognized. Nelson et al. [31] demonstrated the association between the elevated MnSOD enzymatic activity and the upregulation of general MMP expression in HT-1080 fibrosarcoma cells via the hydrogen peroxide-triggered increase of the DNA-binding activity of specific transcription factors. The migratory phenotype of these tumor cells, linked to cytoskeletal reorganization, lamellipodia extension, and disruption of focal adhesions, have been also associated to hydrogen peroxide-mediated modulation of Rac and Rho-mediated signal transduction [32]. Concerning MDA-MB231 cells, MnSOD expression was found positively correlated to the epithelial-mesenchymal transition responsible of their invasive and migratory capacities [33]. In line with literature data, the present results demonstrate that MDA-MB231 cells show an approximately threefold increase of their R.I.I. in the presence of $5 \mu \mathrm{M} \mathrm{MnCl}_{2}$, which is attributable to an elevation of motile activity and erosive capacity towards matrigel. On the other hand, the results obtained with cells cultured in $100 \mu \mathrm{M} \mathrm{MnCl}_{2}$-containing medium indicate that, although the R.I.I. underwent a faint lowering, tumor cells still retain an active motile behavior on matrigel-free filters, even greater than controls, thereby suggesting that Mn regulation of viability/growth rate, locomotory stimulation, and release of ECM-targeted enzymes may rely upon different intracellular pathways and mechanisms.

$\mathrm{Cd}$ is a nonessential element with a long biological half-life of $\sim 25$ years in the human body. It is not involved in enzymatic activities but it was shown to interfere with zinc-dependent intracellular processes, due to their many chemical similarities. Several literature reports have brought evidence about the inhibitory potential of Mn supplementation on intracellular $\mathrm{Cd}$ uptake thereby playing a major role in tissue protection from $\mathrm{Cd}$ toxicity. Competition for both binding sites at the plasma membrane and transmembrane transport systems, and inhibition of $\mathrm{Cd}$-induced reactive oxygen species (ROS) production, lipid peroxidation, and ERK activation are considered as the main reasons for the Mn-dependent alleviation of Cd effect [3,4,14-16,34-36]. Concerning TNBC MDA-MB231 cells, our previous data demonstrated the dose-dependent cytotoxic effect of $\mathrm{CdCl}_{2}$ with an $\mathrm{IC}_{50}$ at $96 \mathrm{~h}$ 
of $5 \mu \mathrm{M}$ concentration. Subsequent molecular studies demonstrated that this treatment induced the upregulation of cellular defense genes such as those coding for Dap kinase and some members of cytosolic/mitochondrial heat shock proteins, caspases, and metallothioneins, and the downregulation of the genes coding for the survival factor Bcl-2, the NF-kB-stimulating AEG-1 protein, and the cytochrome oxidase subunits II and IV. Moreover, an abnormally increased rate of mitochondrial respiration, a massive accumulation of ROS and a derangement of MAPK pattern of expression and synthesis was also found in exposed cells [17-19,37]. To our knowledge, here we present first data focusing on the mitigating activity of $\mathrm{Cd}$ on Mn-induced exacerbation of TNBC cell proliferative and invasive behavior. In fact, the addition of $5 \mu \mathrm{M} \mathrm{CdCl}_{2}$ to the medium containing the different $\mathrm{MnCl}_{2}$ concentrations counteracted the increase of cell number diminishing cell viability/growth rate down to values close to those attributable to the effect of the sole $\mathrm{CdCl}_{2}$. Also, the R.I.I. of coexposed cells decreased drastically with respect to controls. Given that MnSOD is strictly localized into the mitochondria and that the MAPK signaling pathway is responsible of the Mn-triggered proliferative activity [26], it is conceivable that the previously observed alterations induced by $\mathrm{Cd}$ to mitochondria and MAPK signalization in MDA-MB231 cells may be, at least in part, responsible of the suppression of the promoting effects of $\mathrm{MnCl}_{2}$ in the case of cotreatment. Other non-MnSOD-dependent mechanisms may be responsible of the observed effects. In fact, it must be taken into consideration that $\mathrm{Cd}$ and $\mathrm{Mn}$ share a common pathway for entering the cells through transmembrane transport systems and that competition between the two metal has been reported [3,4]. In addition, data have been produced on the competitive inhibition played by $\mathrm{Cd}$ on Mn-binding active sites in different enzymes and other intracellular targets $[34,35,38]$.

\section{Materials and Methods}

\subsection{Cell Cultures}

MDA-MB231 TNBC cells and HB2 immortalized breast epithelial cells [39] (the latter courtesy of Cancer Research, UK), taken from laboratory stocks, were cultured in RPMI 1640 medium (MDA-MB231) and high glucose-DMEM medium plus $5 \mu \mathrm{g}$ hydrocortisone/ $\mathrm{mL}$ and $10 \mu \mathrm{g}$ bovine insulin/mL (HB2), respectively, both purchased from Sigma, St. Louis, MO, USA, supplemented with $10 \%$ fetal calf serum (FCS; ThermoFisher, Waltham MA, USA) and antibiotic/antimycotic mixture ( $100 \mathrm{U} / \mathrm{mL}$ penicillin, $100 \mu \mathrm{g} / \mathrm{mL}$ streptomycin, and $2.5 \mathrm{mg} / \mathrm{L}$ amphotericin B; ThermoFisher), at $37^{\circ} \mathrm{C}$ in a $5 \% \mathrm{CO}_{2}$ atmosphere. Since the only Mn source in routine culture is FCS where the metal is present in varying concentrations, its percentage in the tumor cell-containing media was lowered to $1 \% 4 \mathrm{~h}$ before the proliferation assays and maintained at this concentration during the tests. On the other hand, no reduction of serum concentration was made for HB2 cells due to the demonstrated strong dependency of these cells on $10 \%$ FCS supplement for their sustained growth rate [40].

\subsection{Proliferation Assay}

Cell proliferative behavior was evaluated by crystal violet assay [41]. Cells in exponential growth were plated at a concentration of 5500 cells/well in a 96-well plate, allowed to adhere overnight, and then treated for $24,48,72$, and $96 \mathrm{~h}$ with 1, 5, 10, 50, or $100 \mu \mathrm{M} \mathrm{MnCl}_{2}$. A parallel set of assays was made by exposing cells to the above-mentioned concentrations of $\mathrm{MnCl}_{2}$ in association with $5 \mu \mathrm{M}$ $\mathrm{CdCl}_{2}$. At the end of the incubation cells were stained with $0.2 \%$ crystal violet in $2 \%$ ethanol for $10 \mathrm{~min}$, followed by elution of the bound dye with $1 \%$ SDS. The absorbance of the dissolved crystal violet was measured in an automated microplate reader at $570 \mathrm{~nm}$.

\subsection{In Vitro Chemotaxis and Chemoinvasion Assays}

Cell motile and invasive behaviors were evaluated by a modified Boyden chamber test, essentially as described by [9]. Each "blind well" chamber (top well $=800 \mu \mathrm{L}$, bottom well $=200 \mu \mathrm{L}$; Neuro-Probe, 
Cabin John, MD, USA) accommodated a polyvinylpyrrolidone-free filter polycarbonate filter with an $8-\mu \mathrm{M}$ pore diameter and $50 \mathrm{~mm}^{2}$ exposed area (Nucleopore, Pleasanton, CA/USA).

For chemotaxis assays, in order to optimize cell adhesion, the plastic filters were coated with type I collagen (Sigma, St. Louis, MO, USA) dissolved in $0.1 \%$ acetic acid at the concentration of $20 \mu \mathrm{g} / \mathrm{mL}$ and allowed to dry overnight [42]. For chemoinvasion assays, the filters were coated with $25 \mu \mathrm{g}$ of matrigel, a reconstituted three-dimensional basement membrane matrix from Engelbreth-Holm-Swarm murine sarcoma (Sigma, St. Louis, MO, USA).

Before the assays, the cells were treated with $\mathrm{MnCl}_{2}, \mathrm{CdCl}_{2}$, or both, at the concentrations and for the times which were shown to affect their proliferative behavior, as from the previous assay. Trypsinized control and treated cells were resuspended in FCS-deprived medium after exhaustive washing and seeded at the concentration of $3 \times 10^{5}$ in the upper well of the chamber, whereas fresh $10 \%$ FCS-containing medium was used as chemoattractant in the lower well, as reported by Kamath and coworkers for MDA-MB231 and MCF-7 breast cancer cells [43]. The assays were carried out for $6 \mathrm{~h}$, and after removal of the nonmigrated cells attached to the upper surface of the filters with a cotton swab, those migrated to the lower surface of the filter were fixed with $95 \%$ ethanol, stained with $0.02 \mathrm{~g}$ toluidine blue $/ \mathrm{mL}$, and quantified by counting their number in twelve random fields of the filter at 200-fold magnification, after mounting the filters onto microscope slides with a drop of immersion oil.

The I.I. and the R.I.I. were calculated as follows

$$
\text { I.I. }=\mathrm{N}_{\mathrm{CI}} / \mathrm{N}_{\mathrm{CT}} \times 100
$$

where $\mathrm{N}_{\mathrm{CI}}$ and $\mathrm{N}_{\mathrm{CT}}$ were the number of control or treated cells crossing the filters in parallel chemoinvasion and chemotaxis assays, respectively.

$$
\text { R.I.I. = I.I.t/I.I.c }
$$

where I.I.t and I.I.c were the I.I. of treated and control cells, respectively. R.I.I. values $=1,<1$, and $>1$ are indicative of invasion-ineffective, -restraining, and -promoting effects exerted by the specific treatment, respectively.

\subsection{Statistics}

Statistics was checked through ANOVA test with SigmaStat 4.0 software (SYSTAT, San Jose, CA, USA). A $p$-value $<0.05$ was considered statistically significant.

\section{Conclusions}

Although caution must be exercised in extrapolation of in vitro results to the in vivo situation, the present data further support the concept that human exposure to high environmental concentrations of Mn may increase the risk of accelerating the processes of carcinogenesis and metastasis by prompting the expansion and dissemination of subpopulations of overtly transformed TNBC cells, in line with the findings described in a number of epidemiological reports [7,44,45]. Interestingly, $\mathrm{CdCl}_{2}$ treatment appears to possess the potential to counteract $\mathrm{MnCl}_{2}$-mediated cancer-promoting effects. This might be achieved by cotargeting cellular sites and components, and reprogramming the molecular and biochemical pathways of $\mathrm{MnCl}_{2}$-stimulated TNBC cells. The inhibitory activity of Cd-containing compounds on viability and growth of normal and neoplastic cells and the mitigatory effect provided by Zn-containing molecules have been reported in the literature [46-48]. Taking the limited treatment options against TNBC into account, the specific anticancer modulatory property of $\mathrm{CdCl}_{2}$ towards MDA-MB231 cells here reported looks promising and deserves a more detailed biological characterization of the involved intracellular targets aimed to the possible molecular modeling of specific antineoplastic agents with improved effectiveness towards the inhibition of the spreading of malignant breast cancer. 
Funding: This research was funded by the University of Palermo (Italy), grant FFR 2018.

Acknowledgments: The help of Roberta Rizza and Claudio Lourenço in performing the experiments during their laboratory internship is gratefully acknowledged.

Conflicts of Interest: The authors declare no conflict of interest.

\section{References}

1. Avila, D.S.; Puntel, R.L.; Aschner, M. Manganese in health and disease. In Interrelations between Essential Metal Ions and Human Diseases; Sigel, A., Sigel, H., Sigel, R.K.O., Eds.; Springer: Dordrecht, Germany, 2013; pp. 199-228.

2. Freeland-Graves, J.H.; Mousa, T.Y.; Sanjeevi, N. Nutritional requirements for manganese. In Manganese in Heath and Disease; Costa, G.L., Aschner, M., Eds.; The Royal Society of Chemistry: Cambridge, UK, 2015; pp. 34-78.

3. Himeno, S.; Yanagiya, T.; Fujishiro, H. The role of zinc transporters in cadmium and manganese transport in mammalian cells. Biochimie 2009, 91, 1218-1222. [CrossRef]

4. Fujishiro, H.; Yano, Y.; Takada, Y.; Tanihara, M.; Himeno, S. Roles of ZIP8, ZIP14, and DMT1 in transport of cadmium and manganese in mouse kidney proximal tubule cells. Metallomics 2012, 4, 700-708. [CrossRef]

5. Ismail-Khan, R.; Bui, M.M. A review of triple-negative breast cancer. Cancer Control 2010, 17, $173-176$. [CrossRef]

6. Wu, H.D.; Chou, S.Y.; Chen, D.R.; Kuo, H.W. Differentiation of serum levels of trace elements in normal and malignant breast patients. Biol. Trace Elem. Res. 2006, 113, 9-18. [CrossRef]

7. Choi, R.; Kim, M.J.; Sohn, I.; Kim, S.; Kim, I.; Ryu, J.M.; Choi, H.J.; Kim, J.M.; Lee, S.K.; Yu, J.; et al. Serum trace elements and their associations with breast cancer subgroups in Korean breast cancer patients. Nutrients 2019, 11, 37. [CrossRef] [PubMed]

8. Dearth, R.K.; Hiney, J.K.; Srivastava, V.K.; Hamilton, A.M.; Dees, W.L. Prepubertal exposure to elevated manganese results in estradiol regulated mammary gland ductal differentiation and hyperplasia in female rats. Exp. Biol. Med. 2014, 239, 871-882. [CrossRef]

9. Luparello, C.; Romanotto, R.; Tipa, A.; Sirchia, R.; Olmo, N.; López de Silanes, I.; Turnay, J.; Lizarbe, M.A.; Stewart, A.F. Midregion parathyroid hormone-related protein inhibits growth and invasion in vitro and tumorigenesis in vivo of human breast cancer cells. J. Bone Miner. Res. 2001, 16, 2173-2181. [CrossRef] [PubMed]

10. Gartel, A.L.; Feliciano, C.; Tyner, A.L. A new method for determining the status of p53 in tumor cell lines of different origin. Oncol. Res. 2003, 13, 405-408. [CrossRef] [PubMed]

11. Huovinen, M.; Loikkanen, J.; Myllynen, P.; Vähäkangas, K.H. Characterization of human breast cancer cell lines for the studies on p53 in chemical carcinogenesis. Toxicol. In Vitro 2011, 25, 1007-1017. [CrossRef]

12. Lymburner, S.; McLeod, S.; Purtzki, M.; Roskelley, C.; Xu, Z. Zinc inhibits magnesium-dependent migration of human breast cancer MDA-MB-231 cells on fibronectin. J. Nutr. Biochem. 2013, 24, 1034-1040. [CrossRef]

13. Ju, H.; Li, Y.; Xing, X.; Miao, X.; Feng, Y.; Ren, Y.; Qin, J.; Liu, D.; Chen, Z.; Yang, Z. Manganese-12 acetate suppresses the migration, invasion, and epithelial-mesenchymal transition by inhibiting Wnt/ $\beta$-catenin and PI3K/AKT signaling pathways in breast cancer cells. Thorac. Cancer 2018, 9, 353-359. [CrossRef]

14. Martin, P.; Fareh, M.; Poggi, M.C.; Boulukos, K.E.; Pognonec, P. Manganese is highly effective in protecting cells from cadmium intoxication. Biochem. Biophys. Res. Commun. 2006, 351, 294-299. [CrossRef]

15. Noël, L.; Huynh-Delerme, C.; Guérin, T.; Huet, H.; Frémy, J.M.; Kolf-Clauw, M. Cadmium accumulation and interactions with zinc, copper, and manganese, analysed by ICP-MS in a long-term Caco-2 TC7 cell model. Biometals 2006, 19, 473-481. [CrossRef] [PubMed]

16. Satarug, S.; Kikuchi, M.; Wisedpanichkij, R.; Li, B.; Takeda, K.; Na-Bangchang, K.; Moore, M.R.; Hirayama, K.; Shibahara, S. Prevention of cadmium accumulation in retinal pigment epithelium with manganese and zinc. Exp. Eye Res. 2008, 87, 587-593. [CrossRef]

17. Sirchia, R.; Longo, A.; Luparello, C. Cadmium regulation of apoptotic and stress response genes in tumoral and immortalized epithelial cells of the human breast. Biochimie 2008, 90, 1578-1590. [CrossRef] [PubMed]

18. Cannino, G.; Ferruggia, E.; Luparello, C.; Rinaldi, A.M. Effects of cadmium chloride on some mitochondria-related activity and gene expression of human MDA-MB231 breast tumor cells. J. Inorg. Biochem. 2008, 102, 1668-1676. [CrossRef] 
19. Casano, C.; Agnello, M.; Sirchia, R.; Luparello, C. Cadmium effects on p38/MAPK isoforms in MDA-MB231 breast cancer cells. Biometals 2010, 23, 83-92. [CrossRef] [PubMed]

20. Milne, D.B.; Sims, R.L.; Ralston, N.V. Manganese content of the cellular components of blood. Clin. Chem. 1990, 36, 450-452. [PubMed]

21. Klein, L.D.; Breakey, A.A.; Scelza, B.; Valeggia, C.; Jasienska, G.; Hinde, K. Concentrations of trace elements in human milk: Comparisons among women in Argentina, Namibia, Poland, and the United States. PLoS ONE 2017, 12, e0183367. [CrossRef]

22. Mulay, I.L.; Roy, R.; Knox, B.E.; Suhr, N.H.; Delaney, W.E. Trace-metal analysis of cancerous and noncancerous human tissues. J. Natl. Cancer Inst. 1971, 47, 1-13.

23. Abdelkarim, M.; Vintonenko, N.; Starzec, A.; Robles, A.; Aubert, J.; Martin, M.L.; Mourah, S.; Podgorniak, M.P.; Rodrigues-Ferreira, S.; Nahmias, C.; et al. Invading basement membrane matrix is sufficient for MDA-MB-231 breast cancer cells to develop a stable in vivo metastatic phenotype. PLoS ONE 2011, 6, e23334. [CrossRef] [PubMed]

24. Holley, A.K.; Bakthavatchalu, V.; Velez-Roman, J.M.; St. Clair, D.K. Manganese superoxide dismutase: Guardian of the powerhouse. Int. J. Mol. Sci. 2011, 12, 7114-7162. [CrossRef] [PubMed]

25. Kumar, A.P.; Loo, S.Y.; Shin, S.W.; Tan, T.Z.; Eng, C.B.; Singh, R.; Putti, T.C.; Ong, C.W.; Salto-Tellez, M.; Goh, B.C.; et al. Manganese superoxide dismutase is a promising target for enhancing chemosensitivity of basal-like breast carcinoma. Antioxid. Redox Signal. 2014, 20, 2326-2346. [CrossRef] [PubMed]

26. Kattan, Z.; Minig, V.; Leroy, P.; Dauça, M.; Becuwe, P. Role of manganese superoxide dismutase on growth and invasive properties of human estrogen-independent breast cancer cells. Breast Cancer Res. Treat. 2008, 108, 203-215. [CrossRef] [PubMed]

27. Starcevic, S.L.; Diotte, N.M.; Zukowski, K.L.; Cameron, M.J.; Novak, R.F. Oxidative DNA damage and repair in a cell lineage model of human proliferative breast disease (PBD). Toxicol. Sci. 2003, 75, 74-81. [CrossRef] [PubMed]

28. Ghneim, H.K. The kinetics of the effect of manganese supplementation on SOD2 activity in senescent human fibroblasts. Eur. Rev. Med. Pharmacol. Sci. 2016, 20, 1866-1880. [PubMed]

29. Qin, S.; Liao, X.; Lu, L.; Zhang, L.; Xi, L.; Guo, Y.; Luo, X. Manganese enhances the expression of the manganese superoxide dismutase in cultured primary chick embryonic myocardial cells. J. Integr. Agric. 2017, 16, 2038-2046. [CrossRef]

30. Thongphasuk, J.; Oberley, L.W.; Oberley, T.D. Induction of superoxide dismutase and cytotoxicity by manganese in human breast cancer cells. Arch. Biochem. Biophys. 1999, 365, 317-327. [CrossRef] [PubMed]

31. Nelson, K.K.; Ranganathan, A.C.; Mansouri, J.; Rodriguez, A.M.; Providence, K.M.; Rutter, J.L.; Pumiglia, K.; Bennett, J.A.; Melendez, J.A. Elevated sod2 activity augments matrix metalloproteinase expression: Evidence for the involvement of endogenous hydrogen peroxide in regulating metastasis. Clin. Cancer Res. 2003, 9, 424-432. [PubMed]

32. Connor, K.M.; Hempel, N.; Nelson, K.K.; Dabiri, G.; Gamarra, A.; Belarmino, J.; Van De Water, L.; Mian, B.M.; Melendez, J.A. Manganese superoxide dismutase enhances the invasive and migratory activity of tumor cells. Cancer Res. 2007, 67, 10260-10267. [CrossRef]

33. Loo, S.Y.; Hirpara, J.L.; Pandey, V.; Tan, T.Z.; Yap, C.T.; Lobie, P.E.; Thiery, J.P.; Goh, B.C.; Pervaiz, S.; Clément, M.V.; et al. Manganese superoxide dismutase expression regulates the switch between an epithelial and a mesenchymal-Like phenotype in breast carcinoma. Antioxid. Redox Signal. 2016, 25, 283-299. [CrossRef] [PubMed]

34. Eybl, V.; Kotyzová, D. Protective effect of manganese in cadmium-induced hepatic oxidative damage, changes in cadmium distribution and trace elements level in mice. Interdiscip. Toxicol. 2010, 3, 68-72. [CrossRef]

35. Chaudhary, S.; Iram, S.; Raisuddin, S.; Parvez, S. Manganese pre-treatment attenuates cadmium induced hepatotoxicity in Swiss albino mice. J. Trace Elem. Med. Biol. 2015, 29, 284-288. [CrossRef] [PubMed]

36. Isaev, N.K.; Avilkina, S.; Golyshev, S.A.; Genrikhs, E.E.; Alexandrova, O.P.; Kapkaeva, M.R.; Stelmashook, E.V. $\mathrm{N}$-acetyl-l-cysteine and $\mathrm{Mn}^{2+}$ attenuate $\mathrm{Cd}^{2+}$-induced disturbance of the intracellular free calcium homeostasis in cultured cerebellar granule neurons. Toxicology 2018, 393, 1-8. [CrossRef] [PubMed]

37. Luparello, C.; Longo, A.; Vetrano, M. Exposure to cadmium chloride influences astrocyte-elevated gene-1 (AEG-1) expression in MDA-MB231 human breast cancer cells. Biochimie 2012, 94, 207-213. [CrossRef] 
38. Pan, C.; Liu, H.D.; Gong, Z.; Yu, X.; Hou, X.B.; Xie, D.D.; Zhu, X.B.; Li, H.W.; Tang, J.Y.; Xu, Y.F.; et al. Cadmium is a potent inhibitor of PPM phosphatases and targets the M1 binding site. Sci. Rep. 2013, 3, 2333. [CrossRef]

39. Caradonna, F.; Luparello, C. Cytogenetic characterization of HB2 epithelial cells from the human breast. In Vitro Cell. Dev. Biol. Anim. 2014, 50, 48-55. [CrossRef]

40. Luparello, C.; Librizzi, M.; Asaro, D.M.L.; Cruciata, I.; Caradonna, F. Mid-region parathyroid hormone-related protein is a genome-wide chromatin-binding factor that promotes growth and differentiation of HB2 epithelial cells from the human breast. Biofactors 2018. [CrossRef]

41. Cristal Violet Assay. Available online: http://www2.kumc.edu/soalab/LabLinks/protocols/cvassay.htm (accessed on 8 July 2018).

42. Liu, F.; Verin, A.D.; Wang, P.; Day, R.; Wersto, R.P.; Chrest, F.J.; English, D.K.; Garcia, J.G. Differential regulation of sphingosine-1-phosphate- and VEGF-induced endothelial cell chemotaxis. Involvement of

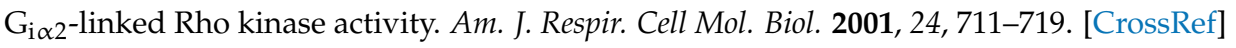

43. Development of Cancer Cell Invasion Assays in a 96 Well Format. Available online: http:/ /www.emdmillipore .com/Web-PR-Site/en_CA/-/USD/ShowDocument-File?ProductSKU=MM_NF-C7748\&DocumentId=201 306.9636.ProNet\&DocumentUID=9950893\&DocumentType=PO\&Language=EN\&Country=NF\&Origin=PDP (accessed on 8 July 2018).

44. Blaurock-Busch, E.; Busch, Y.M.; Friedle, A.; Buerner, H.; Parkash, C.; Kaur, A. Comparing the metal concentration in the hair of cancer patients and healthy people living in the Malwa region of Punjab, India. Clin. Med. Insights Oncol. 2014, 8, 1-13. [CrossRef]

45. White, A.J.; Weinberg, C.R.; O'Meara, E.S.; Sandler, D.P.; Sprague, B.L. Airborne metals and polycyclic aromatic hydrocarbons in relation to mammographic breast density. Breast Cancer Res. 2019, 21, 24. [CrossRef] [PubMed]

46. Pérez, J.M.; Cerrillo, V.; Matesanz, A.I.; Millán, J.M.; Navarro, P.; Alonso, C.; Souza, P. DNA interstrand cross-linking efficiency and cytotoxic activity of novel cadmium(II)-thiocarbodiazone complexes. Chembiochem 2001, 2, 119-123. [CrossRef]

47. Zhang, D.; Liu, J.; Gao, J.; Shahzad, M.; Han, Z.; Wang, Z.; Li, J.; Sjölinder, H. Zinc supplementation protects against cadmium accumulation and cytotoxicity in Madin-Darby bovine kidney cells. PLoS ONE 2014, 9, e103427. [CrossRef]

48. Rukka, N.S.; Kuzmina, L.G.; Albov, D.V.; Shamsiev, R.S.; Mudretsova, S.N.; Davydova, G.A.; Retivov, V.M.; Volkov, P.A.; Kravchenko, V.V.; Apryshko, G.N.; et al. Synthesis, X-ray crystal structure and cytotoxicity studies of zinc(II) and cadmium(II) iodide complexes with antipyrine. Polyhedron 2015, 102, 152-162. [CrossRef]

Sample Availability: Samples of the compounds are not available from the authors.

(C) 2019 by the author. Licensee MDPI, Basel, Switzerland. This article is an open access article distributed under the terms and conditions of the Creative Commons Attribution (CC BY) license (http://creativecommons.org/licenses/by/4.0/). 